\title{
Pre-treatment Apparent Diffusion Coefficient Does Not Predict Therapy Response to Radiochemotherapy in Cervical Cancer: A Systematic Review and Meta-analysis
}

\author{
HANS-JONAS MEYER ${ }^{1 *}$, ANDREAS WIENKE ${ }^{2 *}$ and ALEXEY SUROV ${ }^{3 *}$ \\ ${ }^{1}$ Department of Diagnostic and Interventional Radiology, University of Leipzig, Leipzig, Germany; \\ ${ }^{2}$ Institute of Medical Epidemiology, Biostatistics, and Informatics, \\ Martin-Luther-University Halle-Wittenberg, Halle (Saale), Germany; \\ ${ }^{3}$ Department of Radiology and Nuclear Medicine, University of Magdeburg, Magdeburg, Germany
}

\begin{abstract}
Background/Aim: Magnetic resonance imaging is used for staging purposes in cervical cancer (CC). Diffusionweighted imaging and the apparent diffusion coefficient $(A D C)$ are associated with tumor microstructure. The present analysis sought to compare pre-treatment $A D C$ values to predict treatment outcome of radiochemotherapy for CC based upon a large patient sample. Materials and Methods: MEDLINE library and SCOPUS databases were assessed for suitable articles up to May 2020. The primary endpoint was the mean $A D C$ value of $C C$ according to the treatment response to radiochemotherapy. In total, 16 studies were included in the analysis. Results: For the response group, 416 patients were included in the analysis (72.5\%) and for the noresponse group 158 patients were included (27.5\%). The mean $A D C$ value of patients with CC with treatment response was $0.87 \times 10^{-3} \mathrm{~mm}^{2} / \mathrm{s} \quad(95 \%$ confidence interval $=0.81$ $\left.0.94 \times 10^{-3} \mathrm{~mm}^{2} / \mathrm{s}\right)$, and for the patients with no response was $0.92 \times 10^{-3} \mathrm{~mm}^{2} / \mathrm{s}$ (95\% confidence interval $=0.85-0.98 \times 10^{-3}$ $\left.\mathrm{mm}^{2} / \mathrm{s}\right)$. Conclusion: Pre-treatment ADC values alone cannot be used to reliably predict treatment response to radiochemotherapy in $C C$.
\end{abstract}

This article is freely accessible online.

*All Authors contributed equally to this work

Correspondence to: Hans-Jonas Meyer, MD, Department of Diagnostic and Interventional Radiology, University of Leipzig, Leipzig, Germany. Tel: +49 3419717400, e-mail: Hansjonas.meyer@medizin.uni-leipzig.de

Key Words: Meta-analysis, systematic review, cervical cancer, DWI, ADC, review.
Magnetic resonance imaging (MRI) is clinically of great importance for the diagnosis of cervical cancer (CC) (1-4). It has a high sensitivity and can detect tumor infiltration of adjacent structures. Moreover, due to the addition of diffusion-weighted imaging (DWI), information regarding tumor characteristics such as cellularity can be obtained (57). DWI is a MRI sequence quantifying the Brownian water movement in tissues, which is inversely correlated with cell density in tumors (5-7).

It has been shown that apparent diffusion coefficient (ADC) values differ significantly between adenocarcinoma and squamous cell carcinoma due to different tumor microstructure (8). In addition, correlations with epidermal growth factor and p53 expression were also reported $(7,9)$. These data indicate that ADC values can also reflect tumor biology in a more complex way beyond cellularity alone (10).

There is no doubt regarding the benefit of neoadjuvant and definitive chemotherapy in CC (11). A clear survival benefit was shown for treatment responders, which is also shown by the fact that treatment response is an independent prognostic factor in $\mathrm{CC}$ (12). However, response rates range from approximately $50 \%$ to $92 \%$, whereas the optimal pathological response is lower than $20 \%(11,12)$.

To date, there are no imaging or histopathology modalities which can reliably predict treatment outcome of chemotherapy (11). Yet this approach would be clinically relevant for selecting patients who would benefit from the therapy and those who would not. Thereby, therapy-related toxicity could be reduced if $\mathrm{ADC}$ values were able to predict treatment outcome. Previously, preliminary studies indicated that ADC might be used as predictor of therapy response $(3,4)$.

The present analysis sought to systematically review studies of ADC values in CC according to treatment outcome after radiochemotherapy and to carry out a meta-analysis to 
elucidate whether ADC values differ significantly according to treatment response.

\section{Materials and Methods}

Literature search and inclusion criteria. MEDLINE library and SCOPUS databases were screened for studies investigating ADC values in CC up to May 2020. The following terms for the literature search were used: "Diffusion weighted imaging or diffusionweighted imaging or DWI or Apparent diffusion coefficient or ADC AND cervical cancer OR cervical carcinoma". Secondary references were screened and included, when suitable.

The primary endpoint was defined as the ADC values in patients with CC in regard to treatment outcome.

Studies were included when they met the following criteria: (i) Histopathologically confirmed CC, (ii) MRI with DWI before any form of treatment, and (iii) mean ADC values were reported with standard deviation.

The following were exclusion criteria: (i) Case reports, (ii) reviews, (iii) studies without data of pre-treatment DWI, (iv) articles not in English language, and (v) xenograft or animal model experimental study design.

Article acquisition was performed according to Preferred Reporting Items for Systematic Reviews and Meta-Analyses (PRISMA) statement (13) (Figure 1). In total, 16 articles met the inclusion criteria and were included in the present analysis (14-29).

Quality assessment. The methodological quality of the included studies was independently assessed by two co-authors (A.S. and H.J.M.) using Quality Assessment of Diagnostic Accuracy Studies (QUADAS-2) (30).

Statistical analysis. The analysis was carried out with RevMan 5.3 (2014; Cochrane Collaboration, Copenhagen, Denmark). Heterogeneity of the results was estimated by the inconsistency index I2 $(31,32)$. DerSimonian and Laird random-effect models using inverse-variance weights were calculated without any form of correction (33).

\section{Results}

Figure 2 gives an overview of the methodological quality of the included studies. Overall, the risk of bias was considered low. Patient selection was regarded as overall well-defined within the respective methodology; yet some studies did not clearly define the inclusion criteria sufficiently enough, which can result in some form of potential bias. The index test defined as the MRI with DWI was clearly reported within the studies and should not be considered a source of potential bias. The DWI measurement can be considered as reliable throughout the studies. For flow and timing, there were no serious concerns to report, as in most studies no delay between imaging and treatment procedures were noticed.

The 16 studies included comprised a total of 574 patients with CC. Table I provides an overview of the included studies.

Of the included studies, $10(62.5 \%)$ were of prospective and six $(37.5 \%)$ of retrospective design. Different $1.5 \mathrm{~T}$ MRI scanners were used in five (31.3\%) studies, 3T scanners in 10

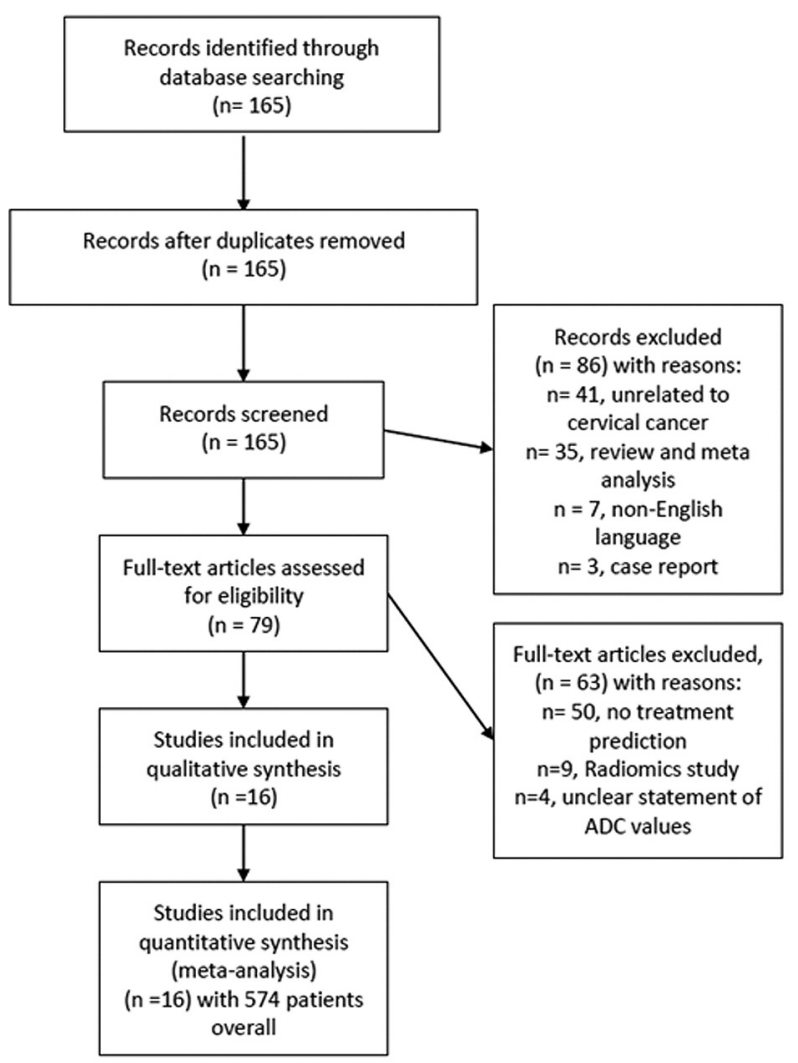

Figure 1. PRISMA flow chart gives an overview of article acquisition. Overall, 16 studies with 574 patients overall were included in the analysis. ADC: Apparent diffusion coefficient.

$(62.5 \%)$ studies, and one study (14) had an unclear scanner technique $(6.2 \%)$. Regarding b-values, most studies used high b-values of 0 and $800 \mathrm{~s} / \mathrm{mm}^{2}$ or higher in 14 studies $(87.5 \%)$. In two studies $(12.5 \%)$, no statement of b-values used was given $(14,16)$. In six studies $(37.5 \%)$, squamous cell carcinomas and other histological entities were investigated, whereas in 10 studies (62.5\%), only squamous cell carcinomas were included. Therefore, most patients had squamous cell carcinomas $(n=537,94.6 \%)$ and only 37 patients $(6.4 \%)$ had other histological entities with 17 patients with adenocarcinomas comprising the second most common entity.

For tumor stages, most studies included different tumor stages ranging from International Federation of Obstetrics and Gynecology-stage IB to IV. Only two studies did not report the exact proportion of tumor stages of their patient sample but only the boundaries of included tumor stages $(16,21)$.

Different treatment regimens were performed in the studies. Concurrent radiochemotherapy was performed in eight studies (50\%), neoadjuvant chemotherapy (25\%) in four studies, definitive radiochemotherapy in two studies $(12.5 \%)$, neoadjuvant radiochemotherapy in one study 


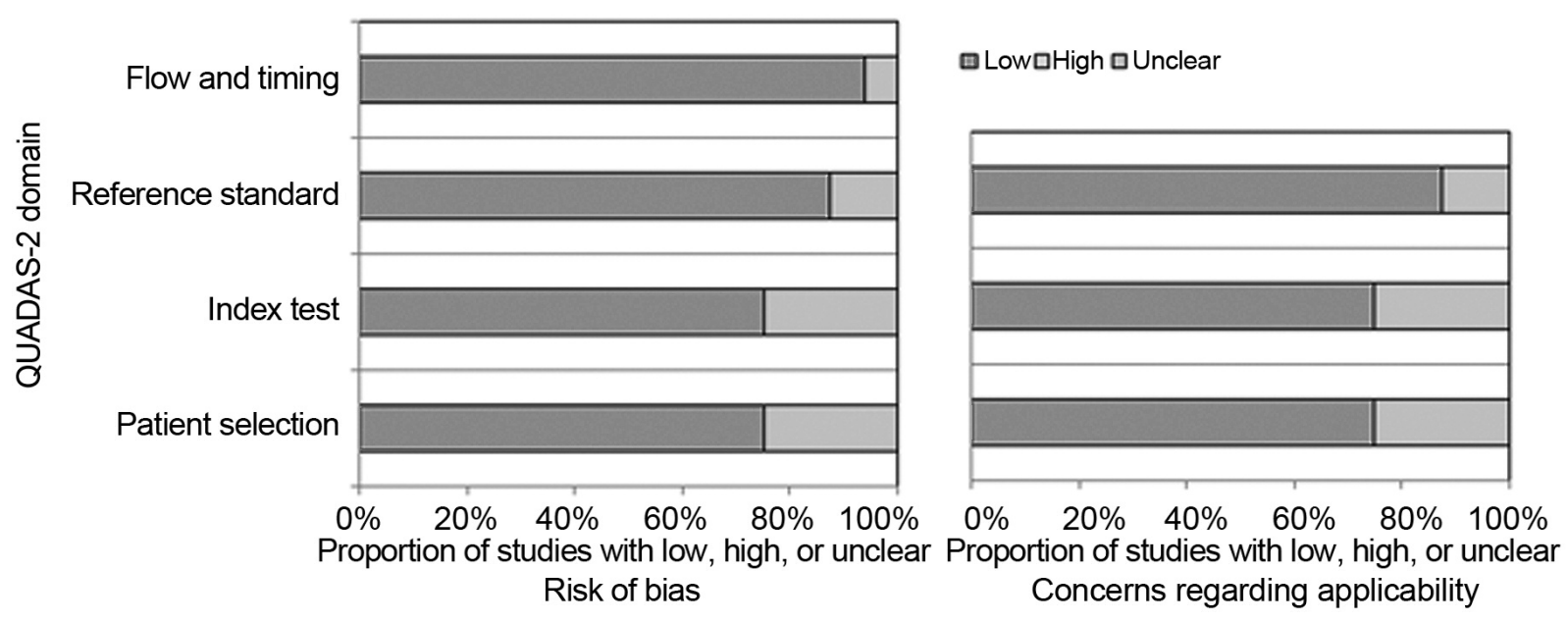

Figure 2. QUADAS-2 quality assessment of the included studies. Most studies showed an overall low potential for sources of bias.

$(6.25 \%)$, and in one study, concurrent radiochemotherapy as well as radiotherapy alone were used (23).

For the responder group, 416 patients were included in the analysis $(72.5 \%)$ and 158 patients for the nonresponders $(27.5 \%)$.

The mean $\mathrm{ADC}$ value for patients with treatment response was $0.87 \times 10^{-3} \mathrm{~mm}^{2} / \mathrm{s} \quad(95 \%$ confidence interval $=0.81-$ $\left.0.94 \times 10^{-3} \mathrm{~mm}^{2} / \mathrm{s} ; \mathrm{Tau}^{2}=0.02, \mathrm{Chi}^{2}=1047.32, \mathrm{df}=15, \mathrm{I}^{2}=99 \%\right)$, and of the patients with no response was $0.92 \times 10^{-3} \mathrm{~mm}^{2} / \mathrm{s}$ (95\% confidence interval $=0.85-0.98 \times 10^{-3} \mathrm{~mm}^{2} / \mathrm{s} ; \mathrm{Tau}^{2}=0.01$, $\mathrm{Chi}^{2}=355.61, \mathrm{df}=11, \mathrm{I}^{2}=97 \%$ ) (Figure 3 ). The high $\mathrm{I}^{2}$ value indicates substantial heterogeneity between the studies. Figure 4 shows these results as a box plot. The ADC values of the groups significantly overlapped with no clear threshold value to distinguish between them.

\section{Discussion}

The present study sought to elucidate whether ADC values of DWI can predict treatment outcome of radiochemotherapy in CC. In short, there were no significant differences between patients with treatment response and those without response according to ADC values.

On the one hand, significantly lower ADC values of patients with treatment response were reported $(27,28)$, but on the other, ADC values were significantly higher for treatment responders (26). Of note, others did not identify significant differences for ADC values according to treatment response $(14,16,25)$. Thus, the present analysis harmonizes the published incongruent results of previous single-centre studies based upon a large sample size.

It is known that radiochemotherapy significantly improves 5 -year overall disease-free survival (hazard ratio=0.78) and 5 -year overall survival (hazard ratio $=0.81$ ) compared to radiotherapy alone (11). There is no doubt that an optimal treatment response is an independent prognostic factor in CC (12). However, the objective response rates range from approximately $50 \%$ to $92 \%$, whereas an optimal pathological response is only found in fewer than $20 \%$ of patients (11).

In the present analysis, different treatment regimens were included, comprising neoadjuvant chemotherapy and concurrent radiochemotherapy, which might have resulted in the identified heterogeneity of the results. Yet the pretreatment ADC value was investigated in the present study, which should be predictive for any form of treatment as a valuable biomarker in clinical routine.

It was extensively reported that ADC values are associated with cellularity, cell density and tumor microstructure $(5,7$, 9, 10). Moreover, ADC values are also correlated with clinically significant histopathological features, comprising proliferative potential and expression of tumor-suppressor gene $\operatorname{TP53}(7,9,10)$. Yet there is still an ongoing debate as to which features of tumor biology are reliably reflected by non-invasive imaging and which not.

Regarding prediction of treatment response by ADC values, there have been promising results for several tumor entities, including head and neck cancer, rectal cancer, and soft-tissue sarcoma (34-36). One can assume that for studies which showed that treatment responders had lower ADC values, a higher cellularity and a higher tumor aggressiveness of the tumor might have resulted in a better treatment response, whereas patients with a higher pre-treatment ADC value might have had lower cellularity and a less aggressive tumor, which resulted in a less effective treatment. On the other hand, there might be the possibility that patients with a more aggressive tumor also have a worse treatment response, as was shown by Wang et al. (26). The relatively high heterogeneity of the underlying data has to be considered. Yet one key finding of 
Table I. Data retrieved from the included studies.

\begin{tabular}{|c|c|c|c|c|c|c|c|c|c|c|}
\hline Author (Ret) & Year & Country & $\begin{array}{l}\text { Study } \\
\text { design }\end{array}$ & $\begin{array}{l}\text { Tesla } \\
\text { strength }\end{array}$ & $\begin{array}{l}\text { b-Value } \\
\left(\mathrm{s} / \mathrm{mm}^{2}\right)\end{array}$ & $\begin{array}{c}\text { Number of } \\
\text { patients }\end{array}$ & $\begin{array}{l}\text { Tumor } \\
\text { entity, } \mathrm{n}\end{array}$ & $\begin{array}{l}\text { FIGO } \\
\text { stage, } n\end{array}$ & Treatment & $\begin{array}{l}\text { Outcome, } \\
\text { n (\%) }\end{array}$ \\
\hline $\begin{array}{l}\text { Akkus Yildirim } \\
\text { et al. (14) }\end{array}$ & 2019 & Turkey & Retrospective & Unclear & Unclear & 63 & Squamous cell & $\begin{array}{c}\text { IB: } 4 \\
\text { IIA: } 4 \\
\text { IIB: } 38 \\
\text { IIIA: } 8 \\
\text { IIIB: } 9\end{array}$ & Definitive CRT & $\begin{array}{c}\text { CR: } 47(75 \%) \\
\text { PR: } 11(17 \%) \\
\text { PD: } 5(8 \%)\end{array}$ \\
\hline $\begin{array}{l}\text { Bian et al. } \\
\text { (15) }\end{array}$ & 2019 & China & Prospective & 3 & $0 / 850$ & 28 & Squamous cell & $\begin{array}{l}\text { IB: } 1 \\
\text { IIB: } 26 \\
\text { IIIB: } 1\end{array}$ & CCRT & $\begin{array}{l}\text { CR: } 22(78.6 \%) \\
\text { PD: } 6(21.4 \%)\end{array}$ \\
\hline $\begin{array}{l}\text { Ciolana et al. } \\
\text { (16) }\end{array}$ & 2019 & Italy & Retrospective & 3 & Unclear & 28 & $\begin{array}{l}\text { Squamous cell: } 22 \\
\text { Adenocarcinoma: } 6\end{array}$ & $\begin{array}{l}\text { IB-IIIB: } \\
\text { NR }\end{array}$ & $\begin{array}{l}\text { Neoadjuvant } \\
\text { chemotherapy }\end{array}$ & $\begin{array}{c}\text { CR: } 3(10.7 \%) \\
\text { PR: } 12(42.9 \%) \\
\text { PD: } 6(21.4 \%) \\
\text { SD: } 7(25 \%)\end{array}$ \\
\hline $\begin{array}{l}\text { Das et al. } \\
\text { (17) }\end{array}$ & 2015 & India & Prospective & 3 & $0 / 800$ & 24 & Squamous cell & $\begin{array}{l}\text { IIB: } 9 \\
\text { IIIB: } 15\end{array}$ & $\begin{array}{l}\text { Neoadjuvant } \\
\text { CRT }\end{array}$ & $\begin{array}{c}\text { CR: } 9(37.5 \%) \\
\text { PR: } 6(25 \%) \\
\text { SD: } 9(37.5 \%)\end{array}$ \\
\hline $\begin{array}{l}\text { Fu et al. } \\
\text { (18) }\end{array}$ & 2012 & China & Prospective & 3 & $0 / 900$ & 30 & Squamous cell & $\begin{array}{l}\text { IB: } 15 \\
\text { IIA: } 9 \\
\text { IIB: } 6\end{array}$ & $\begin{array}{l}\text { Neoadjuvant } \\
\text { chemotherapy }\end{array}$ & $\begin{array}{c}\text { CR: } 1(3.3 \%) \\
\text { PR: } 22(73.3 \%) \\
\text { SD: } 5(16.7 \%) \\
\text { PD: } 2(6.7 \%)\end{array}$ \\
\hline $\begin{array}{l}\text { Fu et al. } \\
\text { (19) }\end{array}$ & 2015 & China & Prospective & 3 & $0 / 900$ & 33 & Squamous cell & $\begin{array}{l}\text { IB: } 13 \\
\text { IIA: } 12 \\
\text { IIB: } 8\end{array}$ & $\begin{array}{l}\text { Neoadjuvant } \\
\text { chemotherapy }\end{array}$ & $\begin{array}{c}\text { CR: } 2(6.1 \%) \\
\text { PR: } 22(66.6 \%) \\
\text { SD: } 7(21.2 \%) \\
\text { PD: } 2(6.1 \%)\end{array}$ \\
\hline $\begin{array}{l}\text { Kuang et al. } \\
(20)\end{array}$ & 2014 & China & Retrospective & 3 & $0 / 1,000$ & 75 & Squamous cell & $\begin{array}{l}\text { IIA: } 38 \\
\text { IIB: } 15 \\
\text { III: } 13 \\
\text { IV: } 9\end{array}$ & CCRT & $\begin{array}{l}\text { CR: } 35(46.7 \%) \\
\text { PR: } 22(29.3 \%) \\
\text { SD: } 18(32.0 \%)\end{array}$ \\
\hline $\begin{array}{l}\text { Liu et al. } \\
\text { (21) }\end{array}$ & 2009 & China & Prospective & 1.5 & $0 / 1,000$ & 17 & Squamous cell & IB-IVB: NR & CCRT & $\begin{array}{c}\text { CR: } 9(52.9 \%) \\
\text { PR: } 7(41.2 \%) \\
\text { SD: } 1(5.9 \%)\end{array}$ \\
\hline $\begin{array}{l}\text { Liu et al. } \\
\text { (22) }\end{array}$ & 2015 & China & Prospective & 1.5 & $0 / 1,000$ & 33 & Squamous cell & $\begin{array}{l}\text { IIB: } 10 \\
\text { IIIA: } 1 \\
\text { IIIIB: } 22\end{array}$ & CCRT & $\begin{array}{l}\text { CR: } 7(21.2 \%) \\
\text { PR: } 26(78.8 \%)\end{array}$ \\
\hline $\begin{array}{l}\text { Makino et al. } \\
\text { (23) }\end{array}$ & 2014 & Japan & Retrospective & 1.5 & $0 / 1,000$ & 25 & $\begin{array}{l}\text { Squamous cell: } 21 \\
\text { Adenocarcinoma: } 4\end{array}$ & $\begin{array}{l}\text { IB: } 3 \\
\text { IIA: } 1 \\
\text { IIB: } 4 \\
\text { IIIA: } 2 \\
\text { IIIB: } 8 \\
\text { IVA: } 3 \\
\text { IVB: } 4\end{array}$ & $\begin{array}{l}\text { CCRT: } 16 \\
\text { RT: } 9\end{array}$ & $\begin{array}{l}\text { CR: } 16(64 \%) \\
\text { Residual tumor: } \\
\quad 9(36 \%)\end{array}$ \\
\hline $\begin{array}{l}\text { Onal et al. } \\
\text { (24) }\end{array}$ & 2016 & Turkey & Retrospective & 1.5 & $0 / 800$ & 44 & Squamous cell & $\begin{array}{c}\text { IB: } 1 \\
\text { IIA: } 3 \\
\text { IIB: } 26 \\
\text { IIIA: } 5 \\
\text { IIIB: } 7 \\
\text { IVA: } 2\end{array}$ & $\begin{array}{l}\text { Definitive } \\
\text { CRT }\end{array}$ & $\begin{array}{l}\text { CR: } 41(93 \%) \\
\text { Residual tumor: } \\
\quad 3(7 \%)\end{array}$ \\
\hline $\begin{array}{l}\text { Ueno et al. } \\
\text { (25) }\end{array}$ & 2017 & Canada & Retrospective & 1.5 & $0 / 1,000$ & 21 & $\begin{array}{l}\text { Squamous cell: } 20 \\
\text { Adenocarcinoma: } 1\end{array}$ & $\begin{array}{c}\text { IB: } 1 \\
\text { IIA: } 1 \\
\text { IIB: } 13 \\
\text { IIIA: } 1 \\
\text { IIIB: } 5\end{array}$ & CCRT & $\begin{array}{c}\text { Responders: } \\
15(71.4 \%) \\
\text { Non-responders } \\
6(28.6 \%)\end{array}$ \\
\hline $\begin{array}{l}\text { Wang et al. } \\
\text { (26) }\end{array}$ & 2016 & China & Prospective & 3 & $0 / 800$ & 42 & $\begin{array}{l}\text { Squamous cell: } 37 \\
\text { Adenocarcinoma: } 4 \\
\text { Adenosquamous: } 1\end{array}$ & $\begin{array}{l}\text { II: } 28 \\
\text { III: } 10 \\
\text { IVA: } 4\end{array}$ & $\begin{array}{l}\text { Neoadjuvant } \\
\text { chemotherapy }\end{array}$ & $\begin{array}{c}\text { CR: } 3(7.1 \%) \\
\text { PR: } 21(50 \%) \\
\text { SD: } 17(40.5 \%) \\
\text { PD: } 1(2.4 \%)\end{array}$ \\
\hline
\end{tabular}


Table I. Continued

\begin{tabular}{|c|c|c|c|c|c|c|c|c|c|c|}
\hline Author (Ret) & Year & Country & $\begin{array}{l}\text { Study } \\
\text { design }\end{array}$ & $\begin{array}{l}\text { Tesla } \\
\text { strength }\end{array}$ & $\begin{array}{l}\text { b-Value } \\
\left(\mathrm{s} / \mathrm{mm}^{2}\right)\end{array}$ & $\begin{array}{c}\text { Number of } \\
\text { patients }\end{array}$ & $\begin{array}{l}\text { Tumor } \\
\text { entity, } \mathrm{n}\end{array}$ & $\begin{array}{l}\text { FIGO } \\
\text { stage, } n\end{array}$ & Treatment & $\begin{array}{l}\text { Outcome, } \\
\text { n (\%) }\end{array}$ \\
\hline $\begin{array}{l}\text { Yang et al. } \\
\text { (27) }\end{array}$ & 2018 & China & Prospective & 3 & $0 / 800$ & 65 & $\begin{array}{l}\text { Squamous cell: } 59 \\
\text { Adenocarcinoma: } 5 \\
\text { Adenosquamous: } 1\end{array}$ & $\begin{array}{l}\text { IB: } 3 \\
\text { IIA: } 4 \\
\text { IIB: } 34 \\
\text { IIIA: } 3 \\
\text { IIIB: } 17 \\
\text { IVA: } 2 \\
\text { IVB: } 2\end{array}$ & CCRT & $\begin{array}{l}\text { CR: } 44(67.7 \%) \\
\text { Residual tumor: } \\
\quad 21(32.3 \%)\end{array}$ \\
\hline $\begin{array}{l}\text { Zhang et al. } \\
\text { (28) }\end{array}$ & 2020 & China & Prospective & 3 & $0 / 800$ & 84 & $\begin{array}{l}\text { Squamous cell: } 69 \\
\text { Other types: } 15\end{array}$ & $\begin{array}{l}\text { IIB: } 14 \\
\text { III: } 36 \\
\text { IV: } 34\end{array}$ & CCRT & $\begin{array}{c}\text { Responders: } \\
58 \text { (CR and } \\
\text { PR; 69.0\%) } \\
\text { Non-responders: } \\
26 \text { (SD and } \\
\text { PD; 31.0\%) }\end{array}$ \\
\hline Zhu et al. (29) & 2016 & China & Prospective & 3 & $0 / 1,000$ & 21 & Squamous cell & $\begin{array}{l}\text { II: } 11 \\
\text { III: } 6 \\
\text { IV: } 4\end{array}$ & CCRT & $\begin{array}{l}\text { CR: } 18(85.7 \%) \\
\text { PR: } 3(14.3 \%)\end{array}$ \\
\hline
\end{tabular}

CCRT: Concurrent radiochemotherapy; CR: Complete response, CRT: radiochemotherapy; PR: partial response, SD: stable disease, PD: progressive disease; FIGO: Fédération Internationale de Gynécologie et d'Obstétrique; NR: numbers not reported.

this study is that ADC values pooled from the published results indicate that $\mathrm{ADC}$ values alone are not able to reliably predict treatment response in $\mathrm{CC}$.

As well as the analysis of pre-treatment ADC values, which might be able to discriminate more aggressive tumors from more benign tumors, the increase of ADC values during treatment seems to be of relevance. This might show tumor regression induced by therapy. Yet in a recent meta-analysis, it was also shown that pre-treatment ADC values were not capable of predicting therapy response in patients with breast cancer in a neoadjuvant setting (37). In short, it is crucial to investigate for which tumor entities DWI and ADC values are useful for treatment prediction and for which ones these cannot be used.

For $\mathrm{CC}$, the treatment response is mainly determined by conventional MRI and morphological measurement of the tumor, considering possible shrinkage (2). Beyond this, a significant T2-weighted signal loss indicates post-treatment fibrosis of the cervix as a result of radiochemotherapy, whereas a decrease in uptake of contrast medium in contrast-enhanced sequences indicates regression of vital tumor tissue, which are both important signs for treatment response (2). However, this assessment can only be made after the treatment and no pretreatment prediction can be made with conventional imaging.

Notably, there are only few histopathological parameters which were investigated for treatment prediction. Only the proliferative index Ki67 and survivin expression remained statistically significant in a multivariate analysis based on 117 squamous cell cervical carcinomas undergoing neoadjuvant chemotherapy and were associated with treatment response (38).
Presumably, the reported differences in the investigated studies were influenced by different scanner technique, measurement of ADC values, and composition of the patient samples. For example, it is a known fact that adenocarcinoma tends to have different ADC values from squamous cell carcinomas (8).

The present analysis suffers from the following limitations. Firstly, the analysis is based upon results of the literature. There might be some publication bias due to the trend of positive or significant reported results. Secondly, only articles in English language were included. Thirdly, only studies employing clinically DWI sequence using two b-values were included. Yet novel DWI techniques such as intravoxel-incoherent motion and diffusion-kurtosis imaging might perform better for treatment prediction in CC $(28,39$, 40). However, no meta-analysis can be performed including these currently with so few articles published. Fourthly, there was substantial inhomogeneity identified in the analysis.

In conclusion, pre-treatment ADC values alone cannot be used to reliably predict treatment response to radiochemotherapy in $\mathrm{CC}$.

\section{Conflicts of Interest}

All Authors confirm that there are no conflicts of interest to be declared.

\section{Authors' Contributions}

All Authors contributed equally to this work. 


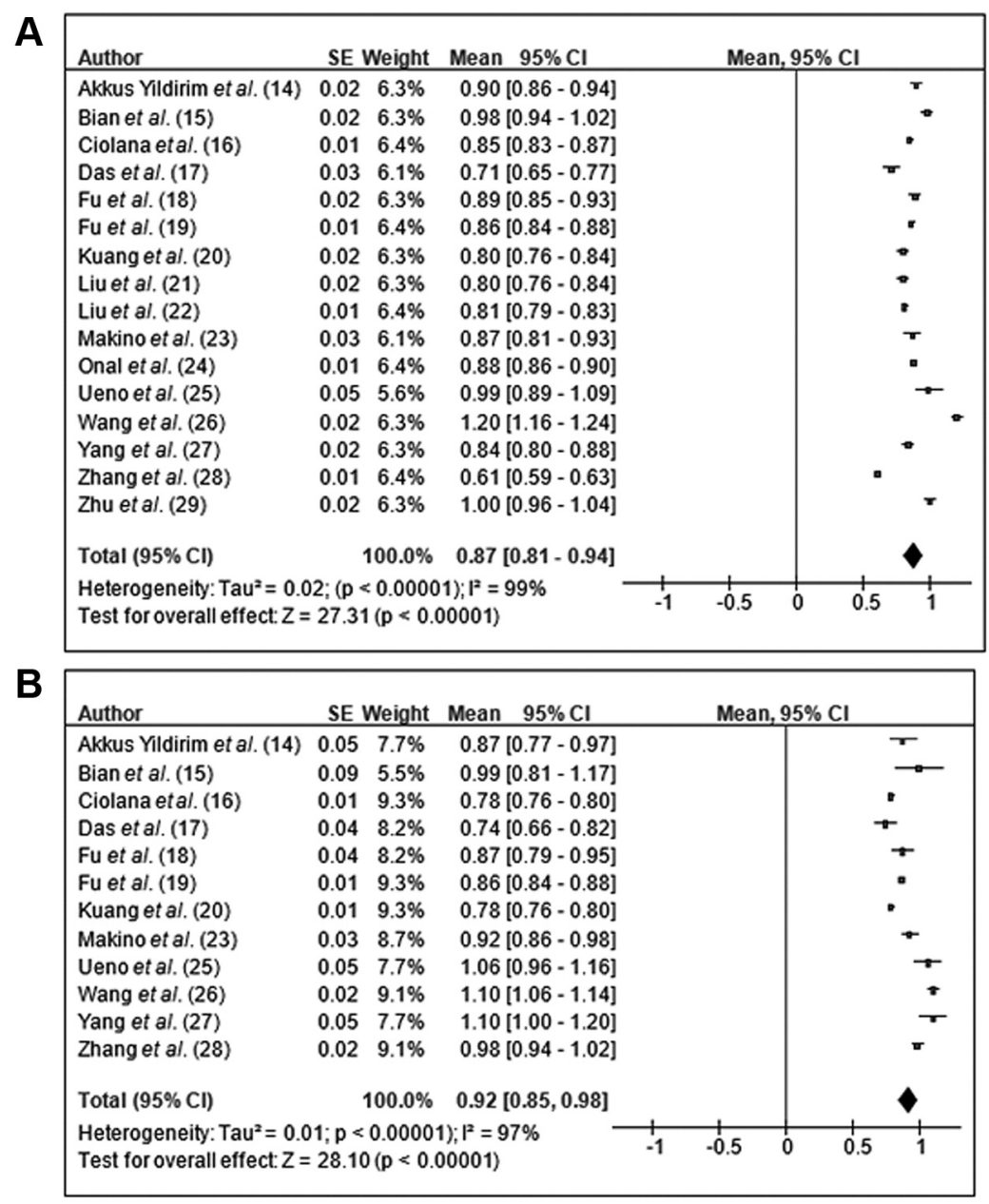

Figure 3. Forrest plots of the mean apparent diffusion coefficient $(A D C)$ values of responders $(A)$ and nonresponders $(B)$ in patients with cervical carcinoma. The mean ADC value of patients with treatment response was $0.87 \times 10^{-3} \mathrm{~mm}^{2} / \mathrm{s}\left(95 \%\right.$ confidence interval=0.81-0.94 $\left.\times 10^{-3} \mathrm{~mm} / \mathrm{s}\right)$, that of patients with no response was $0.92 \times 10^{-3} \mathrm{~mm}^{2} / \mathrm{s}\left(95 \%\right.$ confidence interval $\left.=0.85-0.98 \times 10^{-3} \mathrm{~mm}^{2} / \mathrm{s}\right)$.

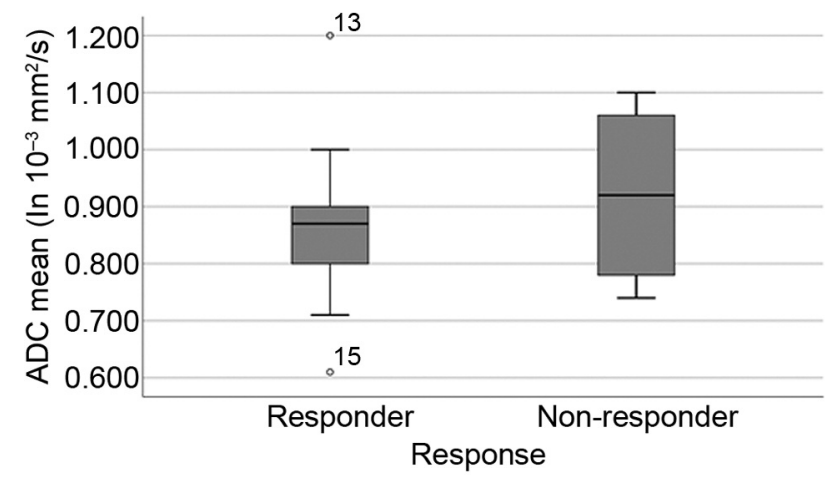

Figure 4. Box plots of the mean apparent diffusion coefficient (ADC) values according to treatment response. The ADC values for groups overlapped significantly, with no clear threshold value to distinguish between them.

\section{References}

1 Mansoori B, Khatri G, Rivera-Colón G, Albuquerque K, Lea J and Pinho DF: Multimodality imaging of uterine cervical malignancies. AJR Am J Roentgenol 215(2): 292-304, 2020. PMID: 32551909. DOI: 10.2214/AJR.19.21941

2 Merz J, Bossart M, Bamberg F and Eisenblaetter M: Revised FIGO staging for cervical cancer - a new role for MRI. Rofo 192(10): 937-944, 2020. PMID: 32731266. DOI: 10.1055/a1198-5729

3 Balcacer P, Shergill A and Litkouhi B: MRI of cervical cancer with a surgical perspective: staging, prognostic implications and pitfalls. Abdom Radiol (NY) 44(7): 2557-2571, 2019. PMID: 30903231. DOI: 10.1007/s00261-019-01984-7

4 Balleyguier C, Sala E, Da Cunha T, Bergman A, Brkljacic B, Danza F, Forstner R, Hamm B, Kubik-Huch R, Lopez C, Manfredi R, McHugo J, Oleaga L, Togashi K and Kinkel K: Staging of 
uterine cervical cancer with MRI: guidelines of the European Society of Urogenital Radiology. Eur Radiol 21(5): 1102-1110, 2011. PMID: 21063710. DOI: 10.1007/s00330-010-1998-x

5 Surov A, Meyer HJ and Wienke A: Correlation between apparent diffusion coefficient (ADC) and cellularity is different in several tumors: a meta-analysis. Oncotarget 8(35): 59492-59499, 2017. PMID: 28938652. DOI: $10.18632 /$ oncotarget.17752

6 Padhani AR, Liu G, Koh DM, Chenevert TL, Thoeny HC, Takahara T, Dzik-Jurasz A, Ross BD, Van Cauteren M, Collins D, Hammoud DA, Rustin GJ, Taouli B and Choyke PL: Diffusion-weighted magnetic resonance imaging as a cancer biomarker: consensus and recommendations. Neoplasia 11(2): 102-125, 2009. PMID: 19186405. DOI: 10.1593/neo.81328

7 Surov A, Meyer HJ, Schob S, Höhn AK, Bremicker K, Exner M, Stumpp P and Purz S: Parameters of simultaneous ${ }^{18} \mathrm{~F}-\mathrm{FDG}-$ PET/MRI predict tumor stage and several histopathological features in uterine cervical cancer. Oncotarget 8(17): 28285-28296, 2017. PMID: 28423698. DOI: 10.18632/oncotarget.16043

8 Lin $\mathrm{Y}, \mathrm{Li} \mathrm{H}$, Chen $\mathrm{Z}$, Ni $\mathrm{P}$, Zhong $\mathrm{Q}$, Huang $\mathrm{H}$ and Sandrasegaran K: Correlation of histogram analysis of apparent diffusion coefficient with uterine cervical pathologic finding. AJR Am J Roentgenol 204(5): 1125-1131, 2015. PMID: 25905952. DOI: 10.2214/AJR.14.13350

9 Schob S, Meyer HJ, Pazaitis N, Schramm D, Bremicker K, Exner M, Höhn AK, Garnov N and Surov A: ADC Histogram Analysis of Cervical Cancer Aids Detecting Lymphatic Metastases-a Preliminary Study. Mol Imaging Biol 19(6): 953962, 2017. PMID: 28315203. DOI: 10.1007/s11307-017-1073-y

10 Meyer HJ, Gundermann P, Höhn AK, Hamerla G and Surov A: Associations between whole tumor histogram analysis parameters derived from ADC maps and expression of EGFR, VEGF, Hif 1-alpha, Her-2 and Histone 3 in uterine cervical cancer. Magn Reson Imaging 57: 68-74, 2019. PMID: 30367998. DOI: $10.1016 /$ j.mri.2018.10.016

11 Gadducci A and Cosio S: Neoadjuvant chemotherapy in locally advanced cervical cancer: review of the literature and perspectives of clinical research. Anticancer Res 40(9): 48194828, 2020. PMID: 32878770. DOI: 10.21873/anticanres.14485

12 Gadducci A, Sartori E, Maggino T, Zola P, Cosio S, Zizioli V, Lapresa M, Piovano E and Landoni F: Pathological response on surgical samples is an independent prognostic variable for patients with Stage Ib2-IIb cervical cancer treated with neoadjuvant chemotherapy and radical hysterectomy: an Italian multicenter retrospective study (CTF Study). Gynecol Oncol 131(3): 640-644, 2013. PMID: 24096111. DOI: 10.1016/j.ygyno.2013.09.029

13 Moher D, Liberati A, Tetzlaff J, Altman DG and PRISMA Group.: Preferred reporting items for systematic reviews and metaanalyses: the PRISMA statement. PLoS Med 6(7): e1000097, 2009. PMID: 19621072. DOI: 10.1371/journal.pmed.1000097

14 Akkus Yildirim B, Onal C, Erbay G, Cem Guler O, Karadeli E, Reyhan $\mathrm{M}$ and Koc Z: Prognostic values of $\mathrm{ADC}_{\text {mean }}$ and $\mathrm{SUV}_{\max }$ of the primary tumour in cervical cancer patients treated with definitive chemoradiotherapy. J Obstet Gynaecol 39(2): 224-230, 2019. PMID: 30354907. DOI: 10.1080/01443615.2018.1492528

15 Bian H, Liu F, Chen S, Li G, Song Y, Sun M and Dong H: Intravoxel incoherent motion diffusion-weighted imaging evaluated the response to concurrent chemoradiotherapy in patients with cervical cancer. Medicine (Baltimore) 98(46): e17943, 2019. PMID: 31725650 . DOI: 10.1097/MD.0000000000 017943
16 Ciolina M, Vinci V, Villani L, Gigli S, Saldari M, Panici PB, Perniola G, Laghi A, Catalano C and Manganaro L: Texture analysis versus conventional MRI prognostic factors in predicting tumor response to neoadjuvant chemotherapy in patients with locally advanced cancer of the uterine cervix. Radiol Med 124(10): 955-964, 2019. PMID: 31254220. DOI: 10.1007/s 11547-019-01055-3

17 Das S, Chandramohan A, Reddy JK, Mukhopadhyay S, Kumar RM, Isiah R, John S, Oommen R and Jeyaseelan V: Role of conventional and diffusion weighted MRI in predicting treatment response after low dose radiation and chemotherapy in locally advanced carcinoma cervix. Radiother Oncol 117(2): 288-293, 2015. PMID: 26475249. DOI: 10.1016/j.radonc.2015.10.006

18 Fu C, Bian D, Liu F, Feng X, Du W and Wang X: The value of diffusion-weighted magnetic resonance imaging in assessing the response of locally advanced cervical cancer to neoadjuvant chemotherapy. Int J Gynecol Cancer 22(6): 1037-1043, 2012. PMID: 22683941. DOI: 10.1097/IGC.0b013e31825736d7

19 Fu C, Feng X, Bian D, Zhao Y, Fang X, Du W, Wang L and Wang X: Simultaneous changes of magnetic resonance diffusionweighted imaging and pathological microstructure in locally advanced cervical cancer caused by neoadjuvant chemotherapy. J Magn Reson Imaging 42(2): 427-435, 2015. PMID: 25328994. DOI: $10.1002 /$ jmri.24779

20 Kuang F, Yan Z, Wang J and Rao Z: The value of diffusionweighted MRI to evaluate the response to radiochemotherapy for cervical cancer. Magn Reson Imaging 32(4): 342-349, 2014. PMID: 24512795. DOI: 10.1016/j.mri.2013.12.007

21 Liu Y, Bai R, Sun H, Liu H, Zhao X and Li Y: Diffusion-weighted imaging in predicting and monitoring the response of uterine cervical cancer to combined chemoradiation. Clin Radiol 64(11): 1067-1074, 2009. PMID: 19822239. DOI: 10.1016/j.crad. 2009.07.010

22 Liu Y, Sun H, Bai R and Ye Z: Time-window of early detection of response to concurrent chemoradiation in cervical cancer by using diffusion-weighted MR imaging: a pilot study. Radiat Oncol 10: 185, 2015. PMID: 26337954. DOI: 10.1186/s13014015-0493-6

23 Makino H, Kato H, Furui T, Morishige K and Kanematsu M: Predictive value of diffusion-weighted magnetic resonance imaging during chemoradiotherapy for uterine cervical cancer. J Obstet Gynaecol Res 40(4): 1098-1104, 2014. PMID: 24320754. DOI: $10.1111 /$ jog. 12276

24 Onal C, Erbay G and Guler OC: Treatment response evaluation using the mean apparent diffusion coefficient in cervical cancer patients treated with definitive chemoradiotherapy. J Magn Reson Imaging 44(4): 1010-1019, 2016. PMID: 26919800. DOI: $10.1002 /$ jmri. 25215

25 Ueno Y, Lisbona R, Tamada T, Alaref A, Sugimura K and Reinhold C: Comparison of FDG PET metabolic tumour volume versus $\mathrm{ADC}$ histogram: prognostic value of tumour treatment response and survival in patients with locally advanced uterine cervical cancer. Br J Radiol 90(1075): 20170035, 2017. PMID: 28508679. DOI: $10.1259 /$ bjr.20170035

26 Wang YC, Hu DY, Hu XM, Shen YQ, Meng XY, Tang H and Li $\mathrm{Z}$ : Assessing the early response of advanced cervical cancer to neoadjuvant chemotherapy using intravoxel incoherent motion diffusion-weighted magnetic resonance imaging: A pilot study. Chin Med J (Engl) 129(6): 665-671, 2016. PMID: 26960369. DOI: $10.4103 / 0366-6999.177995$ 
27 Yang W, Qiang JW, Tian HP, Chen B, Wang AJ and Zhao JG: Multi-parametric MRI in cervical cancer: early prediction of response to concurrent chemoradiotherapy in combination with clinical prognostic factors. Eur Radiol 28(1): 437-445, 2018. PMID: 28779395. DOI: 10.1007/s00330-017-4989-3

28 Zhang H, Zhou Y, Li J, Zhang P, Li Z and Guo J: The value of DWI in predicting the response to synchronous radiochemotherapy for advanced cervical carcinoma: comparison among three mathematical models. Cancer Imaging 20(1): 8, 2020. PMID: 31937371. DOI: 10.1186/s40644-019-0285-6

29 Zhu L, Zhu L, Shi H, Wang H, Yan J, Liu B, Chen W, He J, Zhou Z, Yang X and Liu T: Evaluating early response of cervical cancer under concurrent chemo-radiotherapy by intravoxel incoherent motion MR imaging. BMC Cancer 16: 79, 2016. PMID: 26860361. DOI: 10.1186/s12885-016-2116-5

30 Whiting PF, Rutjes AW, Westwood ME, Mallett S, Deeks JJ, Reitsma JB, Leeflang MM, Sterne JA, Bossuyt PM and QUADAS-2 Group.: QUADAS-2: a revised tool for the quality assessment of diagnostic accuracy studies. Ann Intern Med 155(8): 529-536, 2011. PMID: 22007046. DOI: 10.7326/00034819-155-8-201110180-00009

31 Leeflang MM, Deeks JJ, Gatsonis C, Bossuyt PM and Cochrane Diagnostic Test Accuracy Working Group.: Systematic reviews of diagnostic test accuracy. Ann Intern Med 149(12): 889-897, 2008. PMID: 19075208. DOI: 10.7326/0003-4819-149-12200812160-00008

32 Zamora J, Abraira V, Muriel A, Khan K and Coomarasamy A: Meta-DiSc: a software for meta-analysis of test accuracy data. BMC Med Res Methodol 6: 31, 2006. PMID: 16836745. DOI: 10.1186/1471-2288-6-31

33 DerSimonian R and Laird N: Meta-analysis in clinical trials. Control Clin Trials 7(3): 177-188, 1986. PMID: 3802833. DOI: 10.1016/0197-2456(86)90046-2

34 Chodyla M, Demircioglu A, Schaarschmidt BM, Bertram S, Bruckmann NM, Haferkamp J, Li Y, Bauer S, Podleska LE, Rischpler C, Forsting M, Herrmann K, Umutlu L and Grueneisen J: Evaluation of ${ }^{18} \mathrm{~F}-\mathrm{FDG}$ PET and DWI datasets for the prediction of therapy response of soft tissues sarcomas under neoadjuvant isolated limb perfusion. J Nucl Med, 2020. PMID: 32737246. DOI: 10.2967/jnumed.120.248260
35 Palmisano A, Di Chiara A, Esposito A, Rancoita PMV, Fiorino C, Passoni P, Albarello L, Rosati R, Del Maschio A and De Cobelli F: MRI prediction of pathological response in locally advanced rectal cancer: when apparent diffusion coefficient radiomics meets conventional volumetry. Clin Radiol 75(10): 798.e1-798.e11, 2020. PMID: 32712007. DOI: 10.1016/j.crad.2020.06.023

36 Ravanelli M, Grammatica A, Maddalo M, Ramanzin M, Agazzi GM, Tononcelli E, Battocchio S, Bossi P, Vezzoli M, Maroldi R and Farina D: Pretreatment DWI with histogram analysis of the ADC in predicting the outcome of advanced oropharyngeal cancer with known human papillomavirus status treated with chemoradiation. AJNR Am J Neuroradiol 41(8): 1473-1479, 2020. PMID: 32732272. DOI: 10.3174/ajnr.A6695

37 Surov A, Wienke A and Meyer HJ: Pretreatment apparent diffusion coefficient does not predict therapy response to neoadjuvant chemotherapy in breast cancer. Breast 53: 59-67, 2020. PMID: 32652460. DOI: 10.1016/j.breast.2020.06.001

38 Zhang Y, Yan H, Li R, Guo Y and Zheng R: High expression of surviving predicts poor prognosis in cervical squamous cell carcinoma treated with paclitaxel and carboplatin. Medicine (Baltimore) 98(20): e15607, 2019. PMID: 31096466. DOI: 10.1097/MD.0000000000015607

39 Gao S, Du S, Lu Z, Xin J, Gao S and Sun H: Multiparametric PET/MR (PET and MR-IVIM) for the evaluation of early treatment response and prediction of tumor recurrence in patients with locally advanced cervical cancer. Eur Radiol 30(2): 11911201, 2020. PMID: 31493211. DOI: 10.1007/s00330-01906428-w

40 Zhang Q, Yu X, Ouyang H, Zhang J, Chen S, Xie L and Zhao $\mathrm{X}$ : Whole-tumor texture model based on diffusion kurtosis imaging for assessing cervical cancer: a preliminary study. Eur Radiol, 2021. PMID: 33464399. DOI: 10.1007/s00330-02007612-z

Received January 17, 2021

Revised February 13, 2021

Accepted February 15, 2021 